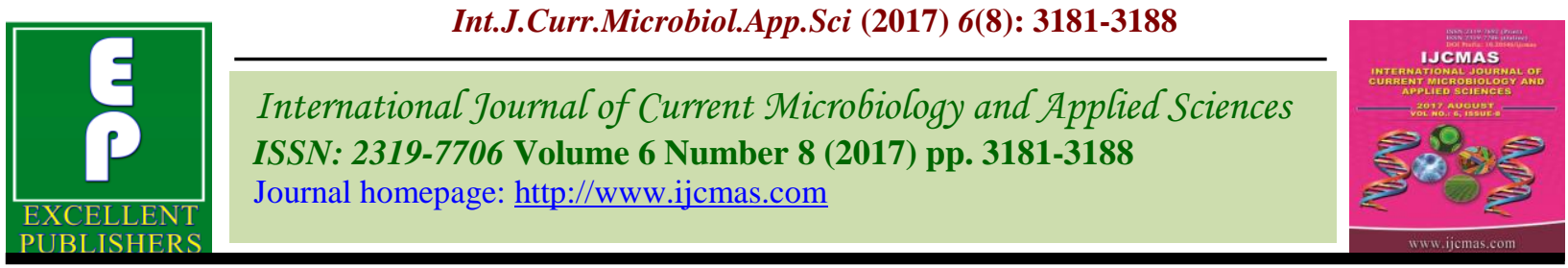

Original Research Article

https://doi.org/10.20546/ijcmas.2017.608.379

\title{
Effect of Breed and Method of Preparation on Yield of Goat Milk Mozzarella Cheese
}

\author{
Surendra Pal Singh ${ }^{1}$, R.B. Sharma ${ }^{2}$ and Gitam Singh ${ }^{3 *}$ \\ ${ }^{1}$ Amardeep Singh Degree College, Firozabad, U.P. -283101, India \\ ${ }^{2}$ Animal Science, K.V.K., Tonk, Rajasthan - 304022, India \\ ${ }^{3}$ National Agricultural Higher Education Project (NAHEP), ICAR, New Delhi, 110012, India \\ *Corresponding author
}

\section{A B S T R A C T}

Keywords

Breed, Method of preparation,

Yield, Goat milk, Mozzarella

Cheese.

Article Info

Accepted:

26 June 2017

Available Online:

10 August 2017
The study was conducted at Goat Products Technology Laboratory of Central Institute for Research on Goats, Makhdoom, Farah, Mathura, Uttar Pradesh and Department of Animal Husbandry and Dairying, R.B.S. College Bichpuri, Agra (U.P.). The goat milk samples were collected early in the morning after the goats were milked completely. The milk samples were analyzed for Fat, Protein, Lactose, Ash, Total Solids and Solids not fat content using Lacto Scan-Automatic Milk Analyzer. Fresh Jakhrana and Jamunapari goat milk was collected within 1.5-2 hour of milking from Livestock Units of Central Institute for Research on Goats, Makhdoom, Farah, Mathura (U.P.). The milk was strained through muslin cloth to remove the dirt. Startar Culture was obtained from National Collection of Dairy Cultures, NDRI, Karnal Haryana, India. The yield of mozzarella cheese made from Jakhrana and Jamunapari goat milk was found to be10.935 \pm 0.079 and $11.201 \pm 0.084$ respectively. Similarly the yield of mozzarella cheese made by direct acid, starter culture and modified method was found to be $10.853 \pm 0.069,11.458 \pm 0.093$ and $10.894 \pm 0.104$ respectively. The overall average value of yield of goat milk mozzarella cheese was $11.068 \pm 0.059$. The statistical analysis revealed that breeds of goat and methods of manufacture significantly affected yield of mozzarella cheese.

\section{Introduction}

Cheese manufacture is one of the classical examples of food preservation, dating from 6000 - 7000 BC. Cheese exploits two classical principles of food preservation, i.e. lactic acid fermentation and reduction of water activity through removal of water and addition of $\mathrm{NaCl}$. Establishment of low redox potential and secretion of antibiotics by starter microorganisms contributes to the storage stability of cheese. The biomedical superiority has not been promoted widely in marketing of goat milk, goat yoghurt and goat cheeses, but has great potential in justifying the uniqueness of goat milk in human nutrition and medicine (Babayan, 1981; Haenlein, 1992) for treating various gastrointestinal disorders and diseases, besides its value in alleviating cow milk allergies.

This includes milk and cheese in northern countries and meat production in countries in the tropics and subtropics. Systems of goat production differ around the world. In the tropics, extensive systems prevail and depend 
on grazing of natural range. This depends mainly on diversification and on subsistence activities, the herd composition and the mobility of the herds (Aich et al., 1999).

Much interest has not been shown to produce hard variety cheese from goat milk as it forms soft and fragile curd which poses technological difficulties (Lacasa, Godina, 1986). However, goat milk is the property item for a few varieties of soft and semi hard cheese which are being marketed as premium cheese in many European countries and in Middle East. Interestingly, goat milk cheese established a potential market even in western countries. The greater proportion of medium chain fatty acids present in goat milk offers these premium cheese a sharper flavour for which they have been recognized (Anifantakis, 1986). The gross composition of goat milk appears to be close to that of cow milk. Fat globules in goat milk are smaller (less than 3 microns) than those in cow milk; but lipid composition and properties of globule membrane at both species are quite similar Jenness (1980). The distribution of lipids in goat milk is like that of cow milk.

Attaie and Richter (2000) determined the goat milk fat globule size by laser size particle analysis. Individual globule of fat in milk ranged from 0.73 to $8.58 \mu \mathrm{m}$ in diameter. The specific surface area of particle in caprine milk was $21,778 \mathrm{~cm}^{2} / \mathrm{ml}$, where as the specific surface area of particle in bovine milk was $17,117 \mathrm{~cm}^{2} / \mathrm{ml}$.

A study on FFA and amino acids in goat milk cheese revealed that both FFA (Caproic, butylic, coprylic acids) and amino acids (glutamic acid, leucine, lysine, valine) increase during months ripening (Baltedjieva et al., 1985). Interestingly goat milk casein was observed to yield less bitter peptide than those of other milk. The lower bitterness in goat milk cheese was attributed to the absence of $\alpha s_{1}$-casein in the goat milk system (Pellisser and Manchon, 1976).

Goat milk cheese was found to have a mild, pleasant and well accepted flavour and waxy smooth and mellow body and texture characteristics. These had the chemical and microbiological activities similar to that of cow milk cheese (Rathore, 1983).

Cheese is a fermented milk product. Technology of fermentation has occupies a place of pride in the food preservation practices since time memorial. Fermented milk products have been reported to have therapeutic, anticholesterolmic, anticarcinogenic and anticariogenic properties. Since it is a fermented product, the off flavour character of goat milk disappears completely. Mozzarella variety of cheese being used most often due to the increased popularity of pizza (International Dairy Foods Association, 2003). The ability of cheese to be cut, sliced, diced or cubed into various shapes, grated, ground and dried offers more versatility for cheese to be used in various cuisines and food application.

Goat milk had a shorter rennet coagulation time than in cow milk (Remuf and Lenoir, 1987; storry et al., 1983; Rathore, 1983), which could be due to higher $\beta$-casein and lower $\alpha$ s-casein, larger micelle size and higher mineralization level. Storry et al., (1983) reported that rennet coagulation time is negatively correlated with $\beta$-casein \& total calcium content and positively with $\alpha_{S} / \beta$ casein ratio.

Coagulum strength is strongly related to total casein concentration, but is unaffected by total fat content or by casein/ fat ratio. However, goat milk has consistently lower curd strength than cow milk despite having similar quantity of casein smaller micelle size give rise to firmness curd than larger micelles, 
at same total casein concentration (Grandison, 1986). This could be the reason for weaker curd in goat milk, which has larger micelle casein as compared to cow and buffalo milks. Curd firmness was also dependent on proportion of $\alpha_{S}$-casein (Grandison et al., 1985), which was less in goat milk as compared to $\beta$-casein. Jairam et al., (1980) and Garnot et al., (1981) reported that fat content of milk hard little effect on curd strength.

The specific gravity content and fat percentage in the milk of Jakhrana as well as Jamunapari goat breeds under farm rearing conditions was significantly higher than that of field rearing conditions. It is due to better feeding in farm rearing conditions but the protein, lactose, ash, total solids and solidsnot-fat in the milk of Jakhrana as well as Jamunapari goat breeds under field rearing conditions were higher than that of farm rearing conditions (Singh and Sharma, 2013).

The conventional method of Mozzarella preparation using rennet is expensive and requires longer time for its preparation. Use of direct acidification method has been popular, since the Mozzarella cheese prepared by this method properly. But it reduces the manufacturing time only to some extent. The present study has been undertaken to reduce the manufacturing time of Mozzarella cheese and to produce rennet free Mozzarella cheese in order to reduce the cost of manufacturing.

A modified method for preparation of Mozzarella cheese was developed to eliminate the use of costly rennet and the maintenance of specific cultures in addition to considerable reduction in the manufacturing time. The process involved pasteurization of goat milk, coagulation using citric acid solution, temperatures manipulation and stretching etc. Therefore, the study has been planned with the following objectives:

\section{Effect of breed and method of preparation on yield of goat milk mozzarella cheese}

\section{Methodology}

The study was conducted at Goat Products Technology Laboratory of Central Institute for Research on Goats, Makhdoom, Farah, Mathura, Uttar Pradesh and Department of Animal Husbandry and Dairying, R.B.S. College Bichpuri, Agra (U.P.).

Fresh Jakhrana and Jamunapari goat milk was collected within 1.5-2 hour of milking from Livestock Units of Central Institute for Research on Goats, Makhdoom, Farah, Mathura (U.P.). The milk was strained through muslin cloth to remove the dirt.

\section{Analysis of milk samples}

The goat milk samples were collected early in the morning after the goats were milked completely. The milk samples were analyzed for Fat, Protein, Lactose, Ash, Total Solids and Solids not fat content using Lacto ScanAutomatic Milk Analyzer.

Startar Culture was obtained from National Collection of Dairy Cultures, NDRI, Karnal Haryana, India. Meito: Mircrobial rennet produced by Mucor pusillus Var. Lindt., Tokyo, Japan and used at the rate of $1 \mathrm{~g} / 1001$ of milk. Commercial grade TATA fine salt was used. Calcium chloride was obtained from Qualigens fine chemicals, Glaxo India Ltd. Mumbai. Sodium citrate was obtained from Ranbaxy Laboratories L.td., Chemical division, SAS Nagar. 90\% Gerbers sulphuric acid of specific gravity 1.84 was obtained from S.D. Fine chemical L.td. Mumbai. Amyl alcohol for milk testing of Ranbaxy laboratories L.td. SAS Nagar was used. All the chemicals and biological reagents were of analytical grade and were procured from Bangalore Genei; Hi-Media; SRL Pvt. Ltd., 
RFCL limited, Glaxo, Qualigens; Fisher chemicals, Sigma chemicals, SD Fine chemicals etc.

\section{Glass wares / Plastic wares}

The glass wares/plastic wares (bottles, glass plates, conical flasks, glass pipette, beakers, measuring cylinder, test tubes, micro pipettes, polythene bags, centrifuge tubes, Crucible, Kjeldahl flask and blue cap bottles etc.) used in present study, were procured from reputed manufacturers (Axygen, Nunc, Tarson, Borosil and ASGI).

\section{Manufacture of Mozzarella Cheese}

Fresh goat milk used for cheese preparation was standardized to $3.5 \%$ fat and $8.5 \%$ solidsnot-fat (SNF). Cultures of Streptococcus thermophiles and Lactobacillua bulgaricus and rennet were procured from the Dairy Microbiology Division, Nation Dairy Research Institute, Karnal. The chemicals used were of analytical grade.

\section{Methods of Mozzarella Cheese preparation}

In each trial, three types of mozzarella cheese were prepared by Direct Acid Method, Starter Culture Method and Modified Method using 4 litres of milk for each type of cheese and were replicated 5 times.

\section{Standardization of milk}

Standardization of milk was done by addition of skim milk or cream with higher or lower fat percentage. Sometimes the addition of skim milk will do to solve the problem. It is necessary to find the relative amount of the original material and the standardizing material to be mixed together to give a product with the desired fat content. Once these relative proportions have been determined, it is easy to calculate the exact amount of each which must be mixed together to give the exact amount of standardizing material. The "Pearsons square" method used to find the relative quantities of the material involved in a standardizing problem.

\section{Procedure for Direct Acid Method}

Mozzarella cheese was made from goat milk using Direct Acid Method as described by Pal and Agnihotri, 2000.

\section{Procedure for Starter Culture Method}

Mozzarella cheese was prepared using 3.004.00 litres of milk in each batch following the methods described by (Pal and Agnihotri, 2000) with slight modifications. Goat milk was pasteurized by the holding $\operatorname{method}\left(63^{\circ} \mathrm{C}\right.$ for 30 minutes) and cooled to $35^{\circ} \mathrm{C}$ Calcium chloride@0.02\% was added to milk Add starter culture (S.thermophilus and L.bulgaricus in the ratio of 1:1) collected from National Collection For Dairy Cultures, NDRI, Karnal.was added at the rate of $2 \%$ for 90 minute to achieve $\mathrm{pH}$ 5.4. Rennet (Meito Sangyo Co. Ltd., Tokyo, Japan) was added at the rate of $1.0 \mathrm{~g} / 100 \mathrm{l}$ of milk and content kept for 45 minutes. The rennet was diluted 40 times with water before addition. After setting the curd was cut and left undisturbed for 10 minute. The curd was then heated gradually with continuous stirring till the curd became slightly hard. The cooking temperature was raised to $38-47^{\circ} \mathrm{C}$ slowly and curd was cooked at this temperature till firm. The whey was drained off completely, after which the curd was immersed in hot water at $83-84^{\circ} \mathrm{C}$. After about a minute, the curd was kneaded, stretched and moulded for proper body and texture development. The hot plastic mass was moulded into ball and then immersed in brine solution $(20 \% \mathrm{v} / \mathrm{w})$ at $4 \pm 1^{\circ} \mathrm{C}$. The cheese was taken out from the brine after $3 \mathrm{~h}$ and dried. Weight was taken and yield on milk weight basis was recorded. Three trials 
were conducted. The product was evaluated for sensory, microbiology and physicochemical parameters.

Yield of mozzarella cheese was recorded and expressed in percentage. Statistical analysis was carried out with the two way RBD (Randomised Block Design) computer statistical programme to see the effect of breed and method of manufacture and their interaction on different quality traits of cheese.

\section{Results and Discussion}

The data obtained on effect of breed and methods of preparation on yield of goat milk mozzarella cheese are presented in Table - 1 .

It is observed from Table - 1 that the yield of mozzarella cheese made from Jakhrana and Jamunapari goat milk was found to be $10.935 \pm 0.079$ and $11.201 \pm 0.084$ respectively. Similarly the yield of mozzarella cheese made by direct acid, starter culture and modified method was found to be $10.853 \pm 0.069, \quad 11.458 \pm 0.093 \quad$ and $10.894 \pm 0.104$ respectively. The overall average value of yield of goat milk mozzarella cheese was $11.068 \pm 0.059$. The interaction between different breeds and methods of manufacture are also presented in above table.

The statistical analysis (Table-2) revealed that breeds of goat and methods of manufacture significantly affected yield of mozzarella cheese. The yield was observed significantly higher in cheese made from Jamunapari goat milk than Jakhrana goat milk. Similarly higher yield of mozzarella cheese was obtained in case of starter culture method followed by modified and direct acid method. The methods of preparation of mozzarella cheese had no significant influence on yield of mozzarella cheese and the values are comparable with the published reports (Kosikowski, 1982). It is possible that similar amount of fat losses in whey and moisture content gave rise to similar yield values by the three methods of manufacturing.

The statistical analysis revealed that breeds of goat and methods of manufacture significantly affected yield of mozzarella cheese. The yield was observed significantly higher in cheese made from Jamunapari goat milk than Jakhrana goat milk. Similarly higher yield of mozzarella cheese was obtained in case of starter culture method followed by modified and direct acid method.

Agrawal and Bhattacharya (1978) recorded the yield and composition of milk of Black Bangal, Barbari and Black Bangal $\times$ Barbari nannies for 90 days from day 7 to 97 of lactation period. The average daily milk yield in Black Bangal, Barbari and their crosses was $3.44 .42, \quad 665.76$ and $564.68 \mathrm{~g}$ respectively. The mean percentage of milk constituents of Black Bangal, Barbari and cross-bred nannies were respectively: total solids, 15.23, 12.66 and 14.29; fat 4.66, 3.83 and 4.92; protein 5.84, 4.13 and 5.07; lactose 4.40, 4.44 and 4.42; and ash $0.77,0.72$ and 0.87 .

Kosikowski (1982) reported that the average yield of commercial Mozzarella cheese is $11.5 \%$ containing $53.6 \%$ moisture made from 3.0 of fat cow milk cheese yield and fat content were significantly higher when buffalo milk alone was used (Bonassi et al., 1982).

Ghosh (1987) also reported that yield of buffalo milk cheese is $14.98 \%$ where as that of cow milk cheese is $12.4 \%$ the cow milk cheese contained slightly higher level of moisture; fat and salt, when as buffalo milk cheese had higher protein and ash. 
Table.1 Effect of breed and method of preparation on yield of goat milk mozzarella cheese

\begin{tabular}{|c|c|c|c|c|}
\hline \multicolumn{5}{|c|}{ MEAN \& S.E. FOR BREED NO. $1 \quad 10.935 \quad 0.079(45)$} \\
\hline \multicolumn{5}{|c|}{ MEAN \& S.E. FOR BREED NO. $211.201 \quad 0.084$ (45) } \\
\hline \multicolumn{5}{|c|}{ MEAN \& S.E. FOR METHOD NO. $1 \quad 10.853 \quad 0.069$ (30) } \\
\hline \multirow{2}{*}{\multicolumn{5}{|c|}{ MEAN \& S.E. FOR METHOD NO. $211.458 \quad 0.093$ (30) }} \\
\hline & 10.894 & 0.104 & (30) & \\
\hline \multicolumn{5}{|c|}{ MEAN \& S.E. OVER ALL $\quad 11.068 \quad 0.059(90)$} \\
\hline \multicolumn{5}{|c|}{ MEAN \& S.E. FOR BREEDNO. 1 x METHOD NO. $1 \quad 10.903 \quad 0.024$ (15) } \\
\hline MEAN \& S.E. FOR BREEDNO. 1 x M & IETHOD & NO. 2 & 11.311 & $0.138(15)$ \\
\hline MEAN \& S.E. FOR BREEDNO. 1 x M & [ETHOD & NO. 3 & 10.592 & $0.145(15)$ \\
\hline MEAN \& S.E. FOR BREEDNO. 2 x M & {$[$ ETHOD } & NO. 1 & 10.803 & $0.136(15)$ \\
\hline MEAN \& S.E. FOR BREEDNO. 2 x M & {$[$ ETHOD } & NO. 2 & 11.605 & $0.116(15)$ \\
\hline MEAN \& S.E. FOR BREEDNO. 2 x M & {$[$ ETHOD $]$} & NO.3 & 11.197 & $0.105(15)$ \\
\hline
\end{tabular}

Note: Figure in parenthesis indicated number of observations.

Table.2 Analysis of Variance

\begin{tabular}{lrrrrr} 
SOURCE OF VARIATION & D.F. & S.S. & M.S.S. & F-VALUE & REMARK \\
\hline 1 BETWEEN BREED & 1 & 1.592 & 1.592 & 7.043 & H.SIG. $1 \%$ \\
2 BETWEEN METHOD & 2 & 6.859 & 3.429 & 15.171 & H.SIG. $1 \%$ \\
3 ERROR & 86 & 19.441 & 0.226 & -------- & \\
\hline & & &
\end{tabular}

NO.OF OBS. SE CD AT 5\% CD AT $1 \%$

\begin{tabular}{|c|c|c|c|c|c|}
\hline BETWEEN TWO BREED NO.1 2 & 45 & 45 & 0.100 & 0.205 & 0.276 \\
\hline BETWEEN TWO METHOD NO.1 2 & 30 & 30 & 0.123 & 0.251 & 0.338 \\
\hline BETWEEN TWO METHOD NO.1 3 & 30 & 30 & 0.123 & 0.251 & 0.338 \\
\hline BETWEEN TWO METHOD NO.2 3 & 30 & 30 & 0.123 & 0.251 & 0.338 \\
\hline
\end{tabular}

Demott (1983) studied that yield of Mozzarella cheese made by adding station culture and direct acid and observed that the cheese made by adding starter culture gave higher recovery of fat protein and total solids than that made by direct acid, in both fresh and recombined milk. Rottigni and Batello (1989) reported that yield of 'pasta filata' cheese such as Mozzarella increased by 0.1 to $0.2 \%$ when freeze dried $S$. thermophilus 
cultures were used for direct inoculation into the vat. Sabikhi and Kanawjia (1992) reported that yield of Mozzarella cheese prepared from direct acidification method from goat milk was $11.80 \%$.

Pal and Agnihotri (2000) observed $12.27 \%$ yield of Mozzarella cheese manufactured from pure goat milk by direct acid method.

In conclusion, the statistical analysis revealed that breeds of goat and methods of manufacture significantly affected yield of mozzarella cheese. The yield was observed significantly higher in cheese made from Jamunapari goat milk than Jakhrana goat milk. Similarly higher yield of mozzarella cheese was obtained in case of starter culture method followed by modified and direct acid method.

\section{References}

Aich, El, A. and Waterhouse, A. 1999. Small ruminants in environmental conservation. Small Ruminant Res., 34: 271-287.

Anifantakis, E.M. 1986. Comparison of physico-chemical properties of ewe's and cow's milk. Bulletin of IDF DOC No. 202: 42-53.

Attaie, R. and Richter, R.L. 2000. Size distribution of fat globule in Goat milk. J. Dairy Sci., 83: 940-944.

Agrawal, K.P. and Bhattacharyya, N.K. 1978. Yield and composition of milk in Black Bengal, Barbari and Black Bengal X Barbari nannies. Indian J. Animal Sci., 48: 882-886.

Babayan, V.K. 1981. Medium chain length fatty acid esters and their medical and nutritional applications. J. Amer. Oil Chem. Soc., (59): 49A-51A.

Baltadjieva, M. Kalatzapoulos, G. Stamenova, V. and Sfakianos, A. 1985. Free fatty acids and amino acids in two cheeses made from goats milk. Lait, 65: 221-241.

Bonassi, I.A. Carialho, J.B. dec. and Villares, J.B. 1982. Use of buffaloes milk for Mozzrella cheese. Dairy Sci., Abstr., 45: 7402

Demott, B.J. 1983. Recovery of milk constituents in Mozzarella like product manufacture from non-fat dry milk and cream by direct acidification at 4 and $35^{\circ}$ C. J. Dairy Sci., 66: 2501-2506.

Ghosh, B.C. 1987. Production packaging and preservation of Mozzarella cheese from buffalo milk using microbial rennet. Ph.D. This is submitted to Kurkshetra university, kurukshetra.

Garnot, P., Rank, T.C. and Olson, N.F. 1981. Influence of protein and fat content of milk on rheological properties of gel formed by chymosin. J. Dairy Sci., 64(Supp 1.1): 60-61.

Grandison, A.S. 1986. Cause of a variation in milk composition and their effect on the coagulant and cheese making. Dairy Industries Int., 51(3): 21-24

Grandison, A.S., Ford, G.D., Millard, D. and Anderon, M. 1985. Interrelationship of chemical composition and coagulating properties of renneted milk from dairy cows grazing rye grass white clover. $J$. Dairy Res., 52: 41-46.

Haenlein, G.F.W. 1992. Role of goat meat and milk in human nutrition. Proceedings of $5^{\text {th }}$ International conferences on Goats (R.M.Acharya, ed.), ICAR, New Delhi, India, Indian Agr. Res. Serv. Publ. Recent Adv. Goat Production II, (2): 575.

I.D.F.A. 2003. International Dairy Foods Association, (2003. 1250, H St., NW, Suit 900, Washington, DC, 20005, www.idfa.org

Jairam, B.T., Vijayalakshmi, B.T. and Main. P.G. 1980. Curd tension of milk India, J. Dairy Sci., 33:17-20.

Jenness, R. 1980. Composition and 
Characteristics of Goat's Milk: Review. 1968-1979. J. Dairy Sci., 63: 16051630.

Kosikowski, F.V. 1982. Cheese and Fermented foods. Edwards Brothers Inc. Michigan, USA.

Lacasa Godina, A. 1986. Hard and Semi-hard cheese from sheep's and goats milk. Bulletin of IDF Doc. No., 202: 98-109.

Pellissier, J.P. and Manchon, P. 1976. Comparative study of the bitter taste of engymic hydrolysate from cow, eve, and goat caseins. J. Food Sci., 41: 231233.

Pal, U.K. and Agnihotri, M.K. 2000. Quality and Shelf life of direct acid Goat milk Mozzarella cheese at refrigerated temperature. Inter. J. Anim. Sci., 15(1): 57-61.

Rathore, M.S. 1983. Cheddar cheese manufacture with an ad mixiture of buffalo, cow and goat milks. Ph. D. This is submitted to the Kurekshetra University, Kurukshetra.

Remuf, F. and Lenoir, J. 1987. Chemico- physical properties of goat milk and their influence on coagulations by rennet. Dairy Sci., Abstr., 49: 1859.

Rottigni, C. and Batello, M. 1989. Development of the characteristics of starter used in pasta Filata cheese. Dairy Sci., Abstr., 52:1912.

Sabikhi, Latha and Kanawjia, S.K. 1992. Effect of admixing of goat and buffalo milks on sensory, compositional and textural characteristics of direct acid Mozzarella cheese. Indian J. Dairy Sci., 45(10): 562-567.

Singh, G. and Sharma, R.B. 2013. Influence of breeds on goat milk composition under field and farm rearing conditions, Indian Res. J. Genet. \& Biotech., 5(4): $258-261$.

Storry, J.E., Grandison, A.S., Millard, D., Owen, A.J. and Ford, G.D. 1983. Chemical composition and coagulating properties of rennet milks from different breed and specific of ruminant. J. Dairy Res., 50: 215-229.

\section{How to cite this article:}

Surendra Pal Singh, R.B. Sharma and Gitam Singh. 2017. Effect of Breed and Method of Preparation on Yield of Goat Milk Mozzarella Cheese. Int.J.Curr.Microbiol.App.Sci. 6(8): 3181-3188. doi: https://doi.org/10.20546/ijcmas.2017.608.379 